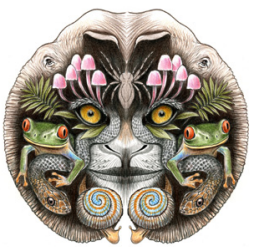

ISSN

Online 0974-7907

Print 0974-7893

OPEN ACCESS

\title{
A tAXONOMIC ACCOUNT OF AMISCHOTOLYPE (COMMELINACEAE) AND NOTES ON THE OCCURRENCE OF PORANDRA IN INDIA
}

\author{
Mayur D. Nandikar ${ }^{1} \&$ Rajaram V. Gurav ${ }^{2}$ \\ ${ }^{1}$ Department of Botany, Goa University, Goa 403206, India \\ ${ }^{2}$ Department of Botany, Shivaji University, Kolhapur, Maharashtra 416004, India \\ ${ }^{1}$ mnandikar@gmail.com (corresponding author), ${ }^{2}$ rvg_botany@unishivaji.ac.in
}

Abstract: An annotated enumeration of Amischotolype (Commelinaceae) in India including one endemic species is given with description, illustrations and key. In addition, notes on the occurrence of genus Porandra in India is provided.

Keywords: Amischotolype, Commelinaceae, India, Porandra, taxonomy.

While working on a revision of Commelinaceae in India the genus Amischotolype Hassk. was studied. The genus is paleotropic and comprises c. 26 species distributed mainly in South, East and Southeast Asia (excluding Sri Lanka) of which four species are strictly found in tropical Africa. In India, the genus is represented by three species (modified after Karthikeyan et al. 1989). Hooker (1894) in his treatment of Flora of British India reported five species, viz., Forrestia mollis Hassk. (=Amischotolype mollissima (Blume) Hassk.), F. griffithii Clarke (=A. griffithii (C.B. Clarke) I.M. Turner), F. marginata Hassk. (=A. marginata (Blume) Hassk.), F. hookeri Hassk. (=A. hookeri (Hassk.) H. Hara) and F. glabrata Hassk. (=A. glabrata Hassk.), of which the first three are known to occur in Java and Malaysia, and are excluded from the present treatment. Recently, Duistermaat (2012) revised the genus Amischotolype for Asia and provided a detailed taxonomic account of the genus. She has described eight new species and one of it ( $A$. dolichandra Duist.) is from India. In the present treatment the detailed description and widened distribution of Amischotolype for India are given.

African Amischotolype tenuis (C.B. Clarke) R.S. Rao as enumerated by Karthikeyan et al. (1989) in India is mistaken. The species is strictly restricted to tropical Africa. In addition, the authors studied Indian specimens in various herbaria that had been identified as $A$. mollisima. However, A. mollissima (Blume) Hassk., is limited in its distribution to Java and Sumatra. In Java it is not known above 600 m elevation, whereas in Sumatra it occurs up to $1420 \mathrm{~m}$ (Duistermaat 2012). The majority of Indian specimens turned out to be either $A$. hookeri or A. glabrata, while a few were identified as a recently described species Amischotolype dolichandra Duist.

Amischotolype dolichandra is closely related to Amischotolype glabrata, and can easily be recognized by short pseudopetioles, glabrous stamen filaments and narrowed, long anthers. In addition, within India, $A$. dolichandra is restricted to the northeastern parts whereas $A$. glabrata is much more widespread from the northeastern to the peninsular region. However, herbarium specimens, in which the diagnostic floral characters were lacking, were not readily distinguishable

DOI: http://dx.doi.org/10.11609/JoTT.03500.5774-80

Editor: Anonymity requested.

Date of publication: 26 May 2014 (online \& print)

Manuscript details: Ms \# 03500 | Received 27 January 2013 | Final received 17 April 2014 | Finally accepted 27 April 2014

Citation: Nandikar, M.D. \& R.V. Gurav (2014). A taxonomic account of Amischotolype (Commelinaceae) and notes on the occurrence of Porandra in India. Journal of Threatened Taxa 6(5): 5774-5780; http://dx.doi.org/10.11609/JoTT.03500. 5774-80

Copyright: @ Nandikar \& Gurav 2014. Creative Commons Attribution 4.0 International License. JoTT allows unrestricted use of this article in any medium, reproduction and distribution by providing adequate credit to the authors and the source of publication.

Funding: Self funded.

Competing Interest: The authors declare no competing interests.
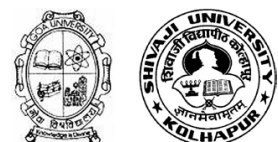

Acknowledgements: We thank Dr. Helena Duistermaat, NCB Naturalis, National Herbarium Netherlands, Leiden for reviewing the manuscript, Prof. S.R. Yadav, Shivaji University, Kolhapur, Prof. M.K. Janarthanam, Goa University, Goa for providing laboratory facilities, the authorities and curators of the herbaria at the Central National Herbarium, Howrah (CAL), at the Madras Herbarium, Coimbatore (MH) and Eastern Circle Herbarium, BSI, Shillong (ASSAM) who have kindly allowed us to examine the specimens and literature. 
from $A$. glabrata. The specimens labeled with $A$. mollisima and $A$. glabrata were screened to determine the distribution of $A$. dolichandra in India, since unfortunately many of which were without flowers or fruits, certain identification could not be made. A mere handful of collections from Sikkim Himalaya and the northeastern states of India turned out to be $A$. dolichandra.

In addition to Amischotolype tenuis, Rao (1971) made two new combinations, namely, $A$. mollissima var. marginata and A. mollissima var. glabrata. But, Rao neither gives descriptions, nor does he cite material for his varieties. Therefore, his new combinations were nomina confusa (for detailed notes please see Duistermaat 2012: 125). We have treated one of his combinations $A$. mollissima var. glabrata as a valid one and a synonym of $A$. glabrata, because Rao (1971: 53) has written: "recent collection of this variety from Andhra Pradesh...new record for the Peninsular India" and it is based on the collection of G.V. Subba Rao 82049 $(\mathrm{MH})$. A screening of the herbarium specimens placed at $\mathrm{MH}$ turned out to be only A. glabrata.

Hong described the genus Porandra in 1974 . It consists of three species and all are known to occur in East Asia (China and Thailand). The identity of the genus from Amischotolype is questionable (Faden 1998), but it is different and separated from Amischotolype by its climbing habit and anther cells opening by apical pores (Thitimetharoch et al. 2003). Duistermaat (2012) stated that $P$. ramosa has teardrop-shaped anthers and after screening the collection of Griffith 5486 (K) from Mishmi Hills, India she has confirmed the occurrence of Porandra in India. The specimen was cited by Clarke (1881: 237) and Hooker (1894: 384) in their treatment of the family Commelinaceae as Forrestia marginata var. rostrata. We have seen only two specimens [A.S. Rao 48050 and J. Joseph 48538 (ASSAM)] from Arunachal Pradesh which allowed us to confirm the climbing habit character (Fig. 3, Image 2). However, it was difficult to examine the opening of the anther from pressed flowers. The straggling or trailing branched habit resembles Porandra ramosa, but more flowering specimens need to be studied to draw any conclusion.

\section{Material and Methods}

Herbarium specimens of all species have been studied from the collections situated at Central National Herbarium, Kolkata (CAL), Madras Herbarium, Coimbatore (MH), and Botanical Survey of India, Eastern Circle, Shillong (ASSAM). The photographs of herbarium sheets (types and other herbarium specimens) were examined digitally through JSTOR Global Plants (http:// plants.jstor.org/) and herbaria webpages of $K, L$ and $P$.

Species descriptions were drawn up using a variety of materials, including herbarium specimens, living plants, preserved flowers and inflorescence and separately collected capsules and seeds. Nomenclature was followed as per the Melbourne Code (McNeill et al. 2012).

Key to the genus (modified after Faden 1998 and Duistermaat 2012)

Plants with various habits, rarely scrambling; anther dehiscent usuallylongitudinal ............................Amischotolype Plants scrambling, climbing or trailing; anther dehiscent poricidal .......................................................... Porandra

\section{Taxonomic Treatment:}

Amischotolype Hassk., Flora 46:392.1863; Pichon, Notul. Syst. 12:233.1946; Hara, Fl. East. Himalaya 1: 399.1966; Morton, J. Linn. Soc., Bot. 60:167-221.1967; Karthik. et al., FI. India. Enum. Monocot. 23.1989. Type: A. glabrata Hassk. (designated by Pichon 1946).

Forrestia A.Rich. in Dumont d'Urville, Voy. Astrolabe 2:1.1834; Miquel, Fl. Ned.Ind. 3:547.1855; Hasskarl, Flora 47:625.1864; Hasskarl, Commelin. Ind. 83.1870; Hooker f., Fl. Brit. India 6: 383.1894; Brückner in Engler \& Prantl, Nat. Pflanzenfam. ed. 2, 15a: 169.1930; Backer and Backh. f., Fl. Java 3: 15.1968; non Rafin.1806. Type: F. hispida A.Rich. [A. hispida (A.Rich.) D.Y.Hong]

Campelia auct., e.g., Blume, Enum. PI. Javae 1:7.1827; Kunth, Enum.pl. 4:109.1843, pro parte; Hasskarl in Miquel, PI. Jungh.154.1852; non L.C.M. Rich. 1808. (after Faden 1998; Duistermaat 2012).

Perennial, small to gigantic herbs; roots fibrous, rather succulent. Stem solid, nodes very short and usually thickened. Leaf sheath tubular, closed, tightly covering the internode, the lower withering and deciduous as the plant matures, generally green, longitudinally veined, glabrous or variously hirsute; leaves distichous, oblong to linear-lanceolate, surface glabrous or variously pubescent, base attenuate, apex acuminate to caudate, submarginal hairs present or absent. Inflorescence very compact and globose or more lax, composed of two to several cincinni. Flowers sessile to subsessile or shortly pedicellate; sepals subequal, succulent; petals free, equal, not clawed; stamens six, equal or subequal, filaments bearded or partially glabrous, anthers dehiscing longitudinally. Capsule dehiscent, white, pink, red, lilac, brown-purple or green, trilocular, valves apically free to fused up to $4 / 5$ of length, ciliate or glabrous. Seeds (1-)2 per locule, embedded in a red, fleshy aril, reniform, surface coarsely 
rugose, hilum linear. $x=9$ (Morton 1967).

Distribution and ecology: Paleotropic, c. 26 species, mainly in South, East and Southeast Asia (excluding Sri Lanka), four species in tropical Africa; primary forest and along forest streams, surviving a long time after disturbance, on rather dry to swampy soils, also on limestone (Duistermaat 2012).

Three species of the genus Amischotolype present in India have been illustrated in the present treatment. The following key will facilitate identification of these species.

1. Capsule exceeded from sepals ...................... A. hookeri

1. Capsule not exceeded from sepals .............................2

2. Stamen filament bearded, capsule valves free [eastern

Pakistan, through India and China to southern Japan] ..........

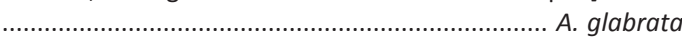

2. Stamen filament glabrous, capsule valves fused

[apparently endemic to India] ........................ A. dolichandra

\section{Amischotolype dolichandra}

Duist. In Gard. Bull. Singapore 64(1): 66. 2012. Type: India, Manipur, Karong, 1050m elevation, 1950, Koelz 26448 (holo- L).

Forrestia mollis Hassk., Flora 47. 628. 1864, nom. illeg.; Hassk., Commelin. Ind. 84. 1870; Clarke in DC., Mon. Phan. 3: 236.1881, pro parte; Hook. f., Fl. Brit. India 6: 383.1894, pro parte.

Amischotolype mollissima of Karthik. et al., FI. India. Enum. Monocot. 23.1989, pro parte (non Hassk. 1863).

Perennial, erect, 1-1.5 m high herb; roots fibrous; basal part of stem ascending and bearing long roots at node; internodes 3-9 cm long, glabrous or hairy. Leaf sheath glabrous or with a line of brown hairs on one side, mouth densely to sparsely ciliate; leaf blades shortly petiolate, oblanceolate, $6-15(-20) \times 3-6 \mathrm{~cm}$, apex acuminate, base attenuate, lower surface glabrous or pubescent, upper surface glabrous. Inflorescence fewmany flowered, densely globose, piercing the sheath. Flowers sessile; sepals pink or red, sparsely ciliate along the margins or glabrous and fleshy; petals as long as sepals, elliptic, white, glabrous; stamen filaments c. $8 \mathrm{~mm}$ long, glabrous; anthers yellow. Capsule trilocular, obovoid, $0.6 \times 0.4 \mathrm{~cm}$, shorter than sepals, apex ciliate, whitish to pink; seeds 1-2 per locule, when two trapezoidal, otherwise broadly ellipsoid, $0.3-0.5 \times 0.2$ $\mathrm{cm}$, embryotega lateral, hilum deeply inserted, forming curved cavity like structure, testa foveate to foveolatescorbiculate, black to metallic black, aril orange [T.M. Hynniewta 84705 (ASSAM)].

Specimens examined: India: 14463 (ASSAM), 19.viii.1958, Tirap Forest Division (NEFA), Changlang District, Arunachal Pradesh, coll. R.S. Rao; 112531 (ASSAM), 5.xiii.2006, Dzuko Valley and Surram Hills,
Kujeree Forest, Manipur, coll. A.A. Mao and R. Gogoi; 31104 (ASSAM), 21.i.1963, North Varnlaphai, Mizo Hills, Mizora, coll. D.B. Deb; 286 (K), vi.1927, Tengawl, Lushai Hills, N.E. Parry; 84705 (ASSAM), 9.xii.1983, Hakchang, Tuensang District, Nagaland, coll. T.M. Hynniewta; 27233 (ASSAM), 28.i.1962, Sabual, North Tripura, Tripura, coll. D.B. Deb.

Flowering and fruiting: Throughout the year.

Distribution and ecology: Apparently endemic to northeastern India; undergrowth of evergreen forest, along stream, in gorge, along roadside, on alluvial fertile soil. For the distribution and conservation status need further detailed documentation.

Note: The species closely resembles $A$. glabrata, which has much wider distribution, longer sepals, stamens with hairy filaments, much shorter anthers, and capsules with basally fused valves (Duistermaat 2012).

\section{Amischotolype glabrata}

Hassk., Flora 46: 392. 1863; Duist., Gard. Bull. Singapore 64(1): 66. 2012. (Fig. 1).

Campelia glabrata auct., sensu Hasskarl in Miquel, PI. Jungh. 154. 1852/53.

Forrestia glabrata (Hassk.) Hassk., Flora 47: 630.1864; Hassk., Commelin. Ind. 94.1870; Clarke, Commelyn. Cyrtandr. Bengal. 62. 1874, t. XLII; Clarke in DC., Mon. Phan. 3: 238.1881; Hook., f., Fl. Brit. India 6: 384.1894; Brückner in Engler and Prantl, Nat. Pflanzenfam. ed. 2: 169.1930.

Forrestia mollissima (Blume) Koord. forma glabrata (Hassk.) Backer, Handb. Fl. Java I, 3:33.1924; 33, pro parte; Backer and Bakhuizen van den Brink, Fl. Java 3:15.1968 pro parte.

Forrestia mollissima (Blume) Koord. var. glabrata (Hassk.) Subba Rao and Kumari, Bull. Bot. Surv. India 12: 209.1970. (nom. inval.: Vienna Code Art. 33.4, no full reference to basionym). Lectotype: Junghuhn s.n., Java: Ungaran prope Medini (L: L0041658 designated by Duistermaat 2012). Other syntypes: Junghuhn s.n., Java: Merapi (L), Gedeet Tangkubanprau (L).

Campelia marginata var. B Blume, Enum. PI. Javae 7.1827; Kunth, Enum. PI. 4: 109.1843. Type: Zippelius s.n., Java (L).

Forrestia hispida auct., sensu C.B.Clarke in DC., Mono. Phan. 3:236.1881. pro parte.

Amischotolype hispida auct., sensu Hong, Acta Phytotax. Sin. 12:4. 461. 1974; McKean, Notes Roy. Bot. Gard. Edinburgh 45:1.153.1988.

Amischotolype mollissima of Karthik. et al., Fl. India. Enum. Monocot. 23.1989. pro parte (non Hassk. 1863).

Scrambling, rhizomatous, 2-2.5 $\mathrm{m}$ high, perennial 


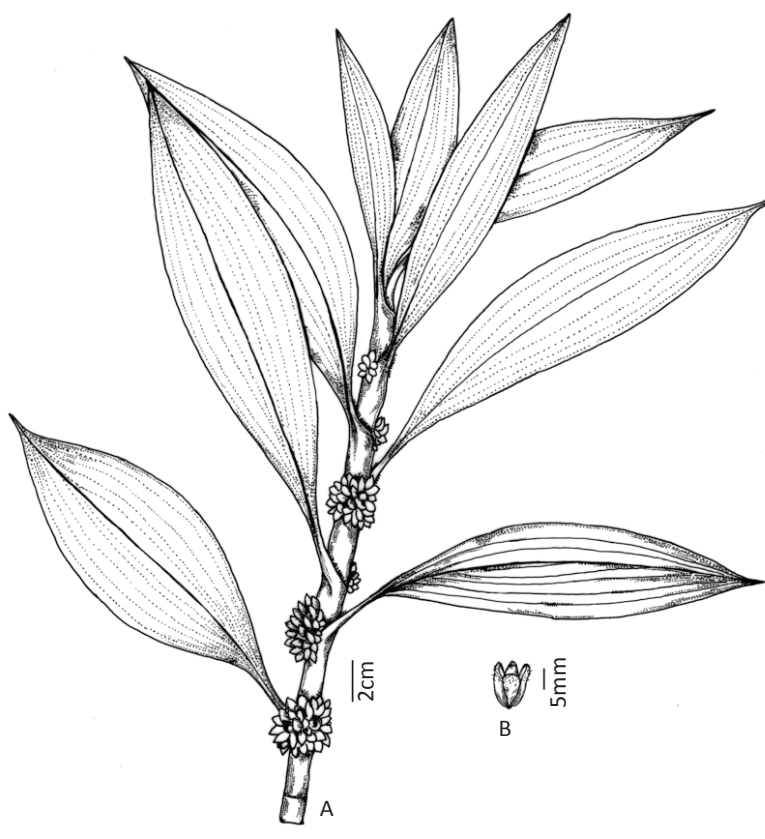

Figure 1. Amischotolype glabrata Hassk.

A - Fruiting twig; B - Capsule [drawn from M.D. Nandikar 22429 (SUK)]. Illustrations drawn by Mayur Nandikar

herb with erect to ascending stem; roots fibrous, numerous on basal, ascending nodes; internodes moderately long and glabrous or puberulous. Leaf sheaths glabrous, mouth usually ciliate, rarely glabrous; blades shortly pseudo-petiolate, oblanceolate, 10$20 \times 3-6.5 \mathrm{~cm}$, apex acute to acuminate, base attenuate, upper surface glabrous while lower sparsely pubescent. Inflorescence dense, 5-15 flowered; flowers shortly pedicellate; sepals green to white or pink, fleshy, persistent, tip hooded; petals $6 \times 3 \mathrm{~mm}$, as long as sepals, elliptic; stamens with filaments c. $11 \mathrm{~mm}$ long, exerted, sparsely bearded with white hairs, anthers deltoid, white or off-white. Capsule $6 \times 5 \mathrm{~mm}$, obovoid, not exerted from sepals, red to pink in colour, upper half sparsely cililate or glabrous; seeds probably 1 or 2 per locule, colour of aril and seed testa not clearly distinguished from herbarium specimens.

Specimens examined: INDIA: A011 (SUK), 9.xii.2011, Hulichal Ghat, Karwar, Karnataka, coll. M.D. Nandikar; 82049, 82050 14.x.1972, Palamagudi, Visakhapatanam District, Andhra Pradesh, coll. G.V. Subba Rao; 73648, 73649 (MH), 23.xii.1967, Minumuluru, Paderu Mandal, Visakhapatanam District, Andhra Pradesh, coll. G.V. Subba Rao. 27879, 14.ii.1962, Kimin River bank, Assam, coll. G. Panigrahi; 97691 (ASSAM) 25.ix.2011, eastern bank of Mehao Lake, Assam, coll. D.K. Singh \& Party; 812 (SUK) 11.x.2012, Shillong, Meghalaya, coll.
M.D. Nandikar; 22429, 12.xii.1969, Tura top, West Garo Hills District, Meghalaya, coll. Panigrahi; 63973 (ASSAM), 7.xii.1975, on the way to Garo Hills (Tura Peak), Meghalaya, coll. M.K.V. Rao; 19048 (CAL), x.1872, Khasia, Shillong, Meghalaya, coll. C.B. Clarke; 44390B (CAL), xii.1886, Shillong, Meghalaya, coll. C.B. Clarke; 1941 (NEHU Herbarium), Tura Peak, s.d., coll. Myrthong; 2174 (CAL), 29.xii.1975, district unknown, Sikkim 1,370m, coll. King; 429 (CAL), 28.ix.1908, Humsong, Sikkim, coll. W.G. Craib; 613(CAL), 11.xii.1908, Siton, Sikkim, coll. W.G. Craib.; 35539(CAL), 26.x.1884, 153m, Garidoora, Darjeeling, West Bengal, coll. C.B. Clarke.

Flowering and fruiting: Throughout the year.

Distribution and ecology: India (Assam, Andhra Pradesh, Arunachal Pradesh, Karnataka, Meghalaya and West Bengal) and other East Asian countries.

Note: Amischotolype glabrata is the most widespread and one of the common species, chiefly occurring in the northeastern parts of India. Also known to occur from eastern Pakistan through China to southern Japan (Ruykyu Islands), south to Nusa Tenggara (Lombok), excluding the Philippines and Sulawesi; primary or disturbed (mountain, oak-laurel) evergreen, mixed or deciduous (monsoon) forest, often near stream, on dry to moist sandy or loamy soil (Duistermaat 2012). Occasionally occurs in the hilly areas, undergrowth of forests of Visakhapatnam District of Andhra Pradesh [Subba Rao 73648 (MH); Subba Rao \& Kumari 1970]. M.D. Nandikar A011, is a new distributional record for Karnataka State of Western Ghats.

\section{Amischotolype hookeri (Fig. 2, Image 1)}

(Hassk.) H. Hara, Fl. E. Himalaya 1: 399. 1966; Karthik. et al., Fl. India. Enum. Monocot. 23.1989; Duist. Gard. Bull. Singapore 64(1): 84. 2012. Fig. 1; 5 A-B.

Forrestia hookeri Hassk. Flora 47: 629. 1864; Hassk., Commelin. Ind. (1870) 89; Clarke, Commelyn. Cyrtandr. Bengal 61.t.XLI. 1874; Clarke in DC., Mon. Phan. 3:237.1881; Hook.f., FI. Brit. India 6:384.1894; Brückner in Engler and Prantl, Nat. Pflanzenfam. ed. 2:169.1930; Rao et al., Proc. Indian Sci. Congr. (1960) 366. Syntypes: Hooker and Thomson s.n., s.d., India contin. regionem tropicam montium Khasiae (inter 1-4000') (CAL, MH, B photo (sh. no. B 10 0296341)).

Rhizomatous, perennial herbs, rhizome prostrate, stem stout and grows up to $100-400 \mathrm{~cm}$ high; internodes moderately 3-4 cm long; nodes swollen, sparsely hairy. Leaf sheath $2-3 \mathrm{~cm}$ long, mouth densely ciliate, margin hairy; leaves crowded at the top, leaf blade oblanceolate, $30-40 \times 10 \mathrm{~cm}$, margin somewhat undulate and sparsely hairy, apex caudate, base gradually to rather abruptly 


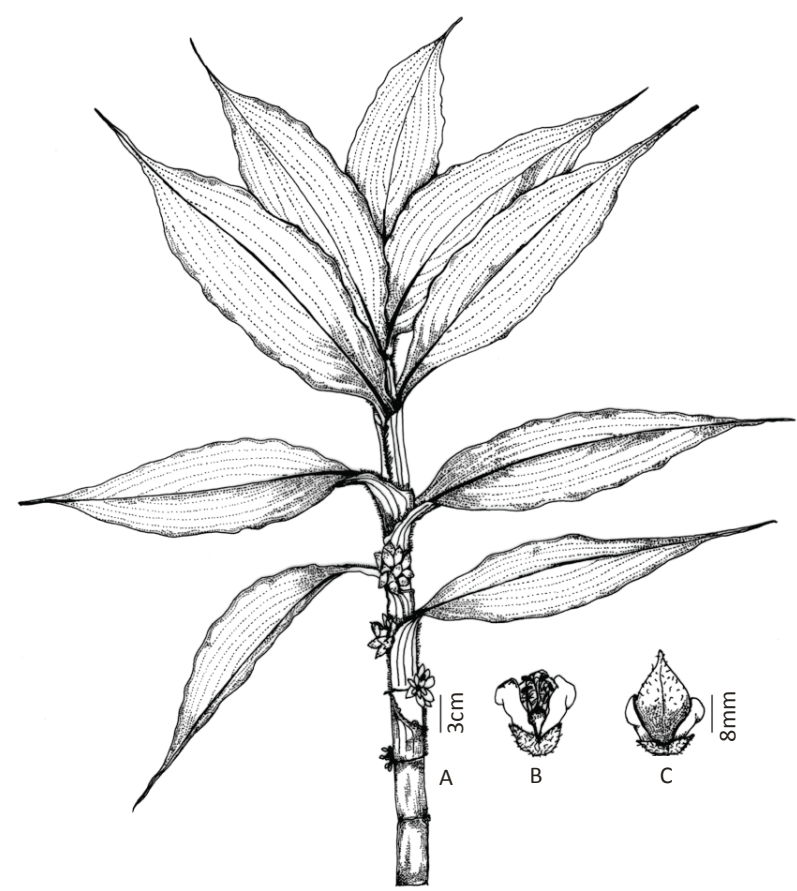

Figure 2. Amischotolype hookeri (Hassk.) H. Hara.

A - Flowering and fruiting twig; B - Flower; C - Capsule [drawn from M.D. Nandikar 1239 (SUK)]. Illustrations drawn by Mayur Nandikar

narrowed into indistinct pseudo-petiole with dense hairs along the margin, veins on lower surface hairy, upper surface glabrous. Inflorescence on erect stem, crowded at nodes, sessile, c. $3 \times 2 \mathrm{~cm}$, dense with branches obscure, 10-15 flowered. Flowers sessile, white to pink; sepals persistent, connate at base, $8 \times 3 \mathrm{~mm}$, green to deep purple, glabrous or rarely sparsely ciliate at margin, tip hooded; petals c. $8 \times 3.5 \mathrm{~mm}$, as long as sepals, white to pale pink, glabrous, fleshy or succulent; stamens filaments c. $1 \mathrm{~mm}$ long; anthers, yellow, opening by a longitudinal slit. Capsule $1-1.5 \times 0.5-0.7 \mathrm{~cm}$, ovoid, much exerted (3-5 $\mathrm{mm}$ ) from sepals, pink or purple, sparsely hairy, hairs long; valves free to fused in basal half, apex acute, lobes absent; seeds two per locule, $5 \times 3 \mathrm{~mm}$, testa variously reticulate, grey, hilum linear, embryotega not distinguished but lateral, embedded in scarlet coloured fleshy aril.

Specimens examined: INDIA: 47747(CAL), 9.ix.1969, Kharem to Wakro Road, Lohit District, Arunachal Pradesh, NEFA, coll. A.S. Rao; 55242, 23.i.1974, Daldali Reserve Forest, Mikir Hills, Karbi Anglong District, Assam, coll. R.S. Rao; 19608 (ASSAM), 16.v.1940, Sibsagar, Hollongpar, Sivasagar District, Assam, coll. R.N. De; 38835 (CAL), 14.xi.1964, Sahargaon, Kamrup District, Assam, coll. A.S. Rao; 102 (CAL), s.date, district unknown, coll. Jenkins; 3689 (MH), xii.1907, below Nasum Vagaleneli, for Fl. Manipur, coll. A. Meebold;
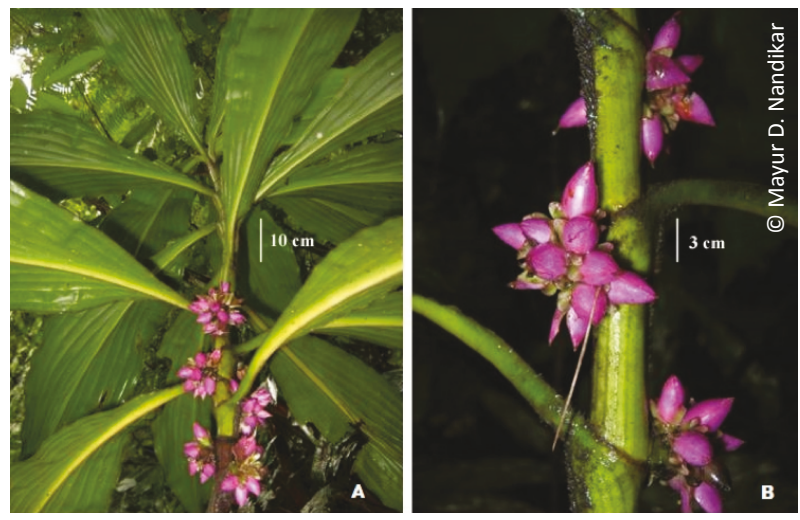

Image 1. A \& B - Amischotolype hookeri (Hassk.) H. Hara

12427, 23.ix.1935, Umsaw forest, Khasi and Jainta Hills District, Meghalaya, coll. Shri Ram Sarma; 43797 (ASSAM), 12.iii.1966, Umling, Nongph District, coll. J. Joseph; 1239 (SUK), 11.x.2012, Experimental Botanical Garden, Umiyam, Shillong, coll. M.D. Nandikar; 36264 (MH), 5.viii.1884, 305m, Mongtow, Sikkim, coll. C.B. Clarke; 2286(x2), 19.xii.1875, 61m, district unknown, Sikkim, coll. G. King; Bishop, 18.ii.1867, Anderson s.n. (sh. no. 488559); 35716 (CAL), 21.xi.1911, Abor. Expd. Makhum, coll. J.H. Burkill.

Flowering and fruiting: Throughout the year.

Distribution and ecology: India and Bangladesh; in northeastern parts of India, in evergreen forests, on slopes, in forest undergrowths.

Note: One of the tall (c. $4 \mathrm{~m}$ ) and robust species of Amischotolype, with large (c. $40 \times 10 \mathrm{~cm}$ ) oblanceolate, undulate leaf blades and large pink coloured (c. $1.5 \mathrm{~cm}$ ) dehiscent capsules, occasionally found in the undergrowth of forests of the northeastern states of India.

Porandra D.Y. Hong in Acta Phytotax. Sin. 12(4): 462. 1974; Faden, Fam. Gen. Vas. PI. 4: 120. 1998. Type: Porandra ramosa D.Y. Hong.

Perennial, rhizomatous, scrambling, climbing or trailing herbs; inflorescence a very compact, globose, subsessile head; flowers bisexual, subsessile; sepals equal, petaloid; petals free, equal, not clawed; stamens six, free, equal, all fertile; filaments bearded; anthers dehiscing by apical pores; capsules trilocular, trivalved; seeds two per locule, arillate.

Three species mainly in China and Thailand, one in India (Arunachal Pradesh).

\section{Porandra ramosa}

D.Y. Hong in Acta Phytotax. Sin. 12(4): 462. 1974; D.Y. Hong and De Filipps in Fl. China 24: 24. 2000. Type: 
China, Yunnan, Feng Qing, T.T. Yü 16255 (holo-PE). Fig. 3 \& Image 2

Climbing or trailing, branched herb, possibly perennial; stem with long internodes, glabrous; leaf sheath 2-4 cm long, glabrous, mouth ciliate; leaves crowded terminally; leaf blade elliptic to lanceolate or oblanceolate, $8-12 \times 3-5 \mathrm{~cm}$, apex acute to acuminate, base attenuate, midrib prominent. Inflorescence a head [usually with (4-) 6-8 flowers; flowers pinkish purple; sepals $6-8 \mathrm{~cm}$ long, elliptic, sparsely ciliate; stamens six, anthers drip-shaped (Thitimetharoch et al. 2003)]; capsule trilocular, ovoid, $10 \times 7 \mathrm{~mm}$, sparsely ciliate; seeds ellipsoid, with bright red aril.

Specimens examined: INDIA: 48050 (ASSAM, CAL), 23.ix.1969, Dalai bridge, Hayuliang, Lohit District, Arunachal Pradesh, coll. A.S. Rao; 48530 (ASSAM, CAL), 9.xii.1969, around Glow village, Lohit District, NEFA, xoll. coll. J. Joseph.

Flowering and fruiting: August to October.

Distribution: China, Thailand and eastern India (incompletely known)

Note: Porandra ramosa is readily distinguished

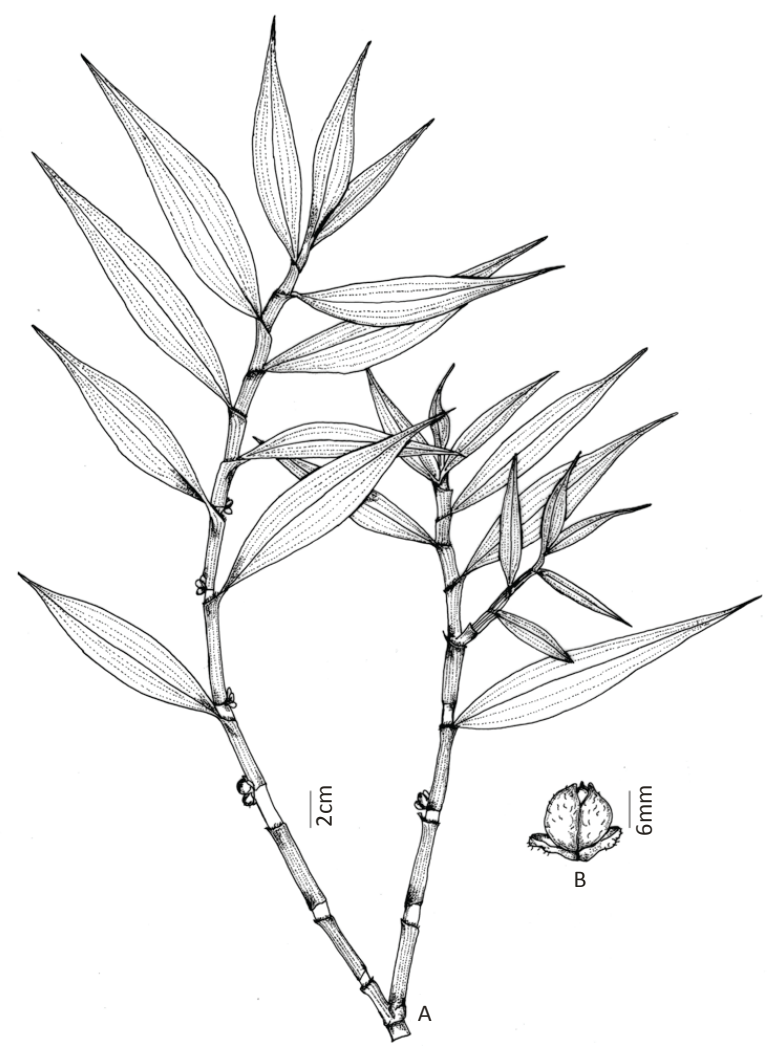

Figure 3. Porandra ramosa D.Y. Hong.

A - Fruiting twig; B - Capsule [drawn from A.S. Rao 48050(ASSAM)]. Illustrations drawn by Mayur Nandikar

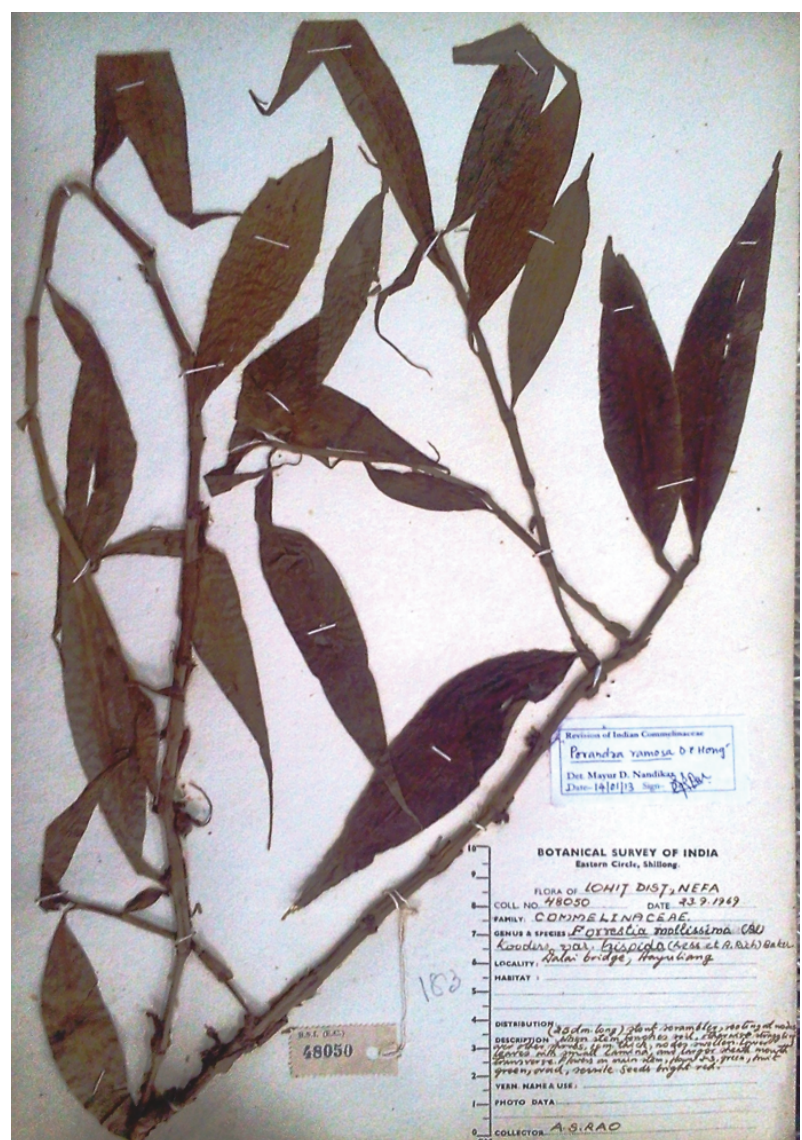

Image 2. Selected herbarium specimen to highlight the occurrence of Porandra ramosa in India [A.S. Rao 48050 (CAL)]

from all other members of the genus by its unique dripshaped anthers and densely pubescent petioles, sepals, capsules and leaves. However, we are unable to find dense pubescence on leaf sheaths, petioles and leaves in the referred specimens, only capsules are sparsely ciliate, which was illustrated by Thitimetharoch et al. (2003) in the original description.

\section{References}

Clarke, C.B. (1881). Commelinaceae, pp. 219-220. In: A. and C. DC., Monographiae phanerogamarum 3. Masson, Paris.

Duistermaat, H. (2012). A taxonomic revision of Amischotolype (Commelinaceae) in Asia. Gardens Bulletin Singapore 64(1): 51-131.

Faden, R.B. (1998). Commelinaceae, pp. 109-128. In: K. Kubitzki (ed.) The Families and Genera of Vascular plants 4. Springer Verlag, Berlin.

Hooker, J.D. (1894). The flora of British India - Volume 6. L. Reeve and Co. London, 374-383pp.

Karthikeyan, S., S.K. Jain, M.P. Nayar \& M. Sanjappa (1989). Flora Indicae Enumerations Monocotyledonae. BSI, Calcutta, 23pp.

McNeill, J., F.R. Barrie, W.R. Buck, V. Demoulin, W. Greuter, D.L. Hawksworth, P.S. Herendeen, S. Knapp, K. Marhold, J. Prado, W.F. Prud'homme van Reine, G.F. Smith, J.H. Wiersema \& N.J. Turland (eds). (2012). International Code of Botanical Nomenclature 
(Melbourne Code) adopted by the Eighteenth International Botanical Congress Melbourne, Australia July 2011. Regnum Veg. 154.

Morton, J.K. (1967). The Commelinaceae of West Africa: a biosystematic survey. Journal of Linnaean Society, Botany 60(382): 167-221; $\quad$ http://www.dx.doi.org/10.1111/j.1095-8339.1967. tb00085.x

Rao, G.V.S. \& G.R. Kumari (1970). New records of plants from South India - III, Bulletin of Botanical Survey of India 12(1-4): 209.

Rao, R.S. (1971). Notes on Indian Commelinaceae - nomenclature and distribution. Maharashtra Vidyan Mandir Patrika 6(2): 52-55.

Thitimetharoch, T., P. Chantaranothai \& R.B. Faden (2003). The Genus Porandra (Commelinaceae) in Thailand. Thai Forest Bulletin (Botany) 31: 141-148. 